\title{
ANALISIS POTENSI LONGSOR LERENG BUKIT TUI KELURAHAN TANAH HITAM KOTA PADANG PANJANG SUMATERA BARAT MENGGUNAKAN APLIKASI SLIDE V6.0
}

\author{
Yoszi Mingsi Anaperta ${ }^{1}$, Septian Andika Putra ${ }^{2}$ \\ ${ }^{1,2}$ Prodi Teknik Pertambangan, Universitas Negeri Padang \\ e-mail: ${ }^{1}$ Yosziperta@yahoo.co.id, ${ }^{2}$ septianandikapura6@gmail.com
}

\begin{abstract}
Tui Hill is a limestone hill lined south of Padang Panjang. It is located between Rao-Rao Village and Tanah Hitam. Based on the results of investigations of researchers on the slopes of Bukit Tui limestone in the coordinates $S 0^{\circ} 28^{\prime} 21.3^{\prime \prime E} 100^{\circ} 24^{\prime} 00.4^{\prime \prime}$ which are in the Tanah Hitam Village, there are many weak fields such as burly, steep slope geometry, influence on earthquake vibrations, and rainfall the high can lead to landslides on slopes, potential for landslides on the slopes of research can endanger road users and community settlements on slope locations. This study aims to analyze the potential of landslides based on the physical and mechanical properties of intact rocks, using the boundary equilibrium method. Then make reinforcement recommendations so that slope conditions are safe / stable. Based on the results of analysis and calculations in saturated conditions with the influence of earthquake factors $0,7-0,9 \mathrm{~g}$ the values of FK 1,461, 1,295, and 1,144 were obtained. From the results of the analysis, the slope is unsafe I unstable. In the original condition with $0.9 \mathrm{~g}$ earthquake factor, FK 1.364 is obtained. Based on the results of analysis and calculations, the slope reinforcement recommendation used is the wire mesh installation method (wiremesh) in slope face.
\end{abstract}

Keywords: Slopes, Landslides, Boundary Equilibrium, Saturated Condition, Slope Strengthening.

\section{INTISARI}

Bukit Tui adalah bukit kapur yang berjajar di selatan Padang Panjang. Letaknya berada antara Kelurahan Rao-Rao hingga Tanah Hitam. Berdasarkan hasil investigasi peneliti pada lereng batu kapur Bukit Tui di kordinat $\mathrm{S}^{\circ} 28^{\prime} 21.3^{\prime \prime} \mathrm{E} 100^{\circ} 24^{\prime} 00.4^{\prime \prime}$ yang berada di Kelurahan Tanah Hitam dijumpai banyaknya bidang lemah berupa kekar, geometri lereng yang terjal, pengaruh terhadap getaran gempa, dan curah hujan yang tinggi dapat memicu terjadinya longsoran pada lereng. Potensi akan terjadinya longsoran pada lereng penelitian dapat membahayakan pengguna jalan dan pemukiman masyarakat di lokasi lereng. Penelitian ini bertujuan untuk menganalisis potensi longsor berdasarkan sifat fisik, dan mekanik batuan utuh, dengan menggunakan metode kesetimbangan batas. Kemudian membuat rekomendasi perkuatan agar kondisi lereng menjadi aman/stabil. Berdasarkan hasil analisis dan perhitungan dalam kondisi jenuh dengan pengaruh faktor gempa 0,7 - 0,9g didapatkan nilai FK 1,461, 1,295, dan 1,144. Dari hasil analisis tersebut maka lereng dalam keadaan tidak aman/tidak stabil, Dalam kondisi asli dengan faktor gempa 0,9g didapatkan nilai FK 1,364 Berdasarkan hasil analisis dan perhitungan, maka rekomendasi perkuatan lereng yang digunakan adalah dengan metode perkuatan pemasangan jaring kawat (wiremesh) di muka lereng.

Kata Kunci : Lereng, Longsor, Kesetimbangan batas, Kondisi jenuh, Perkuatan lereng. 


\section{PENDAHULUAN}

Sumatera Barat merupakan salah satu wilayah yang perlu diwaspadai terhadap potensi terjadinya longsor. Hal ini dikarenakan Sumatera Barat merupakan salah satu dari deretan daerah aktif tektonik dan vulkanik yang terletak pada pertemuan Lempeng Indo-Australia dan Lempeng Eurasia, pergerakan lempeng tersebut memicu banyaknya bencana alam, salah satunya adalah longsor.

Lereng merupakan bagian dari infrastruktur jalan wilayah berbukit yang keberadaannya turut berperan dalam menunjang kelancaran moda transportasi darat, sementara faktor lainnya adalah tingkat keamanan, kenyamanan, waktu tempuh dalam perjalanan dan faktor kendaraan itu sendiri. Konstruksi jalan yang baik memerlukan perencanaan, pembangunan, penataan dan pemeliharaan yang handal, mulai dari pengetahuan tanah dasar (subgrade) sampai material konstruksi jalan[1].

Longsor berdampak sangat kompleks terhadap perubahan bentuk suatu lahan maupun pada kondisi lingkungan yang ada pada lahan tersebut. Bencana ini berkaitan erat dengan kondisi alam seperti jenis tanah, jenis batuan, curah hujan, kemiringan lahan serta penutupan lahan. Selain itu faktor manusia juga sangat menentukan terjadinya bencana longsor seperti alih fungsi lahan yang tidak bijak, penggundulan hutan, pembangunan permukiman pada wilayah dengan topografi yang curam[2].

Salah satu wilayah di Sumatera Barat yang perlu diwaspadai terhadap potensi terjadinya longsor diantaranya adalah lereng Bukit Tui kelurahan Tanah Hitam kecamatan Padang Panjang Barat Kota Padang Panjang. Bukit Tui adalah bukit batu kapur yang berjajar di selatan Padang Panjang, letaknya berada antara Kelurahan Rao-Rao hingga Tanah Hitam. Di lokasi lereng Bukit Tui Keluarahan Tanah Hitam ini pernah terjadinya longsoran besar di Tahun 1987, dan gempa besar 7,6 SR pada tahun 1926.

Akibat longsoran tersebut menyebabkan 136 Korban (Arsip Kota Padang Panjang, 2012).

Hasil investigasi peneliti pada lereng batu kapur Bukit Tui di lokasi S0²8'21,3" E100 $24^{\prime} 00,4 "$ Pada lereng dijumpai banyaknya bidang lemah berupa kekar pada lereng yang dapat menyebabkan terjadinya potensi longsor. Lokasi lereng berada tepi jalan dan pemukiman warga sekitar. Kondisi lereng penelitian yang tinggi dan terjal menjadi salah satu faktor yang menyebabkan terjadinya potensi longsoran. Tinggi lereng di lokasi penelitian adalah $\pm 21 \mathrm{~m}$, dan sudut kemiringan $75^{\circ}$. Potensi akan terjadinya longsoran pada lereng penelitian dapat menyebabkan tertutupnya jalan sehingga menghambat lalu lintas pengguna jalan dan juga dapat membahayakan pemukiman warga. Peta lokasi kesampaian daerah dapat dilihat pada gambar 1 berikut ini.

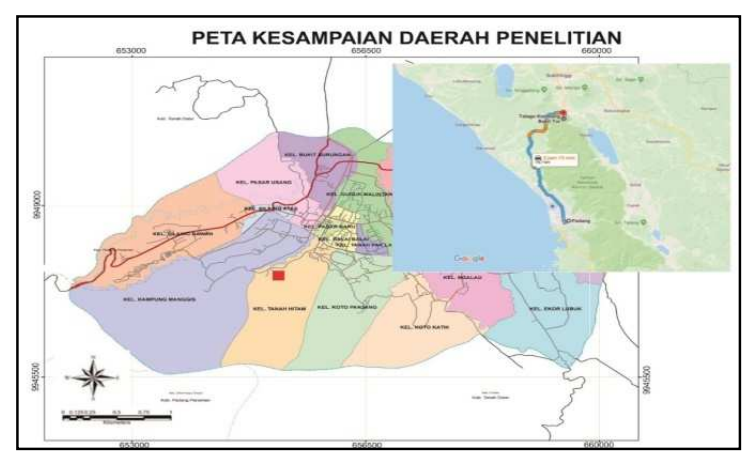

Gambar 1. Area Lokasi Penelitian

Berdasarkan peta zonasi gempa Padang Panjang tergolong ke zona geteran gempa yang tinggi. Besarya nilai getaran akibat gempa di Kota Padang Panjang berkisar 0.8-0.9g. Getaran yang diakibatkan oleh gempa bumi tersebut akan mengakibatkan terganggunya distribusi tegangan pada lereng batu kapur yang sebelumnya berada dalam kondisi mantap.

Potensi longsoran pada lereng lokasi penelitian dipicu juga dengan intensitas curah hujan yang tinggi di Kota Padang Panjang. Kota Padang Panjang secara klimatologi memiliki curah hujan yang cukup tinggi. Curah hujan ratarata pertahun mencapai $3.295 \mathrm{~mm}$ dengan jumlah hari hujan pertahun rata-rata 235-265 hari hujan pertahun. Curah hujan yang tinggi dapat membuat lereng dalam kondisi jenuh sehingga mempengaruhi kondisi kestabilan lereng.

Kemantapan lereng batuan selalu dipengaruhi oleh beberapa faktor antara lain: geometri lereng, struktur geologi, kondisi air 
tanah, sifat fisik dan mekanik batuan serta gayagaya yang bekerja pada lereng[3].

Klasifikasi jenis-jenis longsoran pada lereng batuan diantaranya yaitu longsoran busur, longsoran bidang, longsoran baji dan longsoran guling[4].

Karena berbahayanya dampak longsoran maka perlu adanya solusi untuk meminimalisir terjadinya longsoran. Untuk meminimalisir terjadinya longsoran dapat dilakukan melalui penelitian sebagai mitigasi terhadap bencana longsor. Faktor keamanan lereng perlu diketahui untuk memastikan apakah lereng tersebut aman bagi aktivitas masyarakat di sekitar lereng. Jika lereng diketahui dalam keadaan kurang aman maka perlu dilakukan analisis kembali tentang bagaimana menentukan perkuatan terhadap geometri yang sesuai dengan lereng tersebut.

\section{PENDEKATAN PEMECAHAN MASALAH}

Jenis penelitian ini termasuk kedalam jenis penelitian terapan (Applied Rresearch). Penelitian terapan berfungsi untuk mencari solusi tentang masalah-masalah tertentu, tujuan utamanya adalah pemecah masalah sehingga hasil penelitian dapat dimanfaatkan untuk kepentingan manusia baik secara individu atau kelompok maupun keperluan industri atau politik dan bukan untuk wawasan keilmuan semata[5].

Pada penelitian ini data primer didapat penulis dengan cara mengambil langsung data yang dibutuhkan di lapangan, sedangkan data sekunder didapat penulis dari berbagai sumber baik jurnal, media online serta instansi terkait Kota Padang Panjang.

1. Pengambilan Data di Lapangan

a. Geometri lereng

Data yang diambil pada saat pengambilan data geometri adalah tinggi lereng dan sudut kemiringan lereng. Tinggi lereng didapatkan dengan cara memarking dengan GPS titik di dasar lereng sampai titik puncak lereng, kemudian hasil dari memarking tersebut di plot ke komputer dengan menggunakan software BaseCamp untuk mendapatkan gambar penampang lereng. Sudut kemiringan lereng diukur dengan bantuan alat kompas geologi.

b. Pengukuran struktur diskontinuitas Pengukuran struktur geologi bertujuan untuk mendapatkan parameterparameter yang akan digunakan untuk menentukan klasifikasi massa batuan dengan cara yaitu: penentuan lokasi pengukuran diskontinuitas pada lereng, pemberian tanda terdapatnya diskontinuitas pada garis scanline, pengukuran strike, dip. Amati dan catat bebrapa parameter yang nanti akan digunakan pada klasifikasi massa batuan.

c. Pengambilan sampel batuan

Bebarapa sampel diambil di empat titik sccanline yang berbeda untuk mewakili lereng secara keseluruhan.

d. Data Sekunder

- Peta topografi

- Peta geologi

- Peta hidrogeologi

- Peta zonasi gempa

- Data curah hujan

2. Pengujian Laboratorium

a. Uji Sifat Fisik Batuan

Prosedur pengujian sifat fisik batuan adalah: langkah pertama penimbangan berat contoh asli, langkah kedua perendaman sampel kedalam air selama 24 jam lalu ditimbang untuk mendapatkan berat jenuh, langkah ketiga timbang sampel dalam keadaan tergantung didalam air saat perendaman untuk mendapatkan berat tergantung, langkah keempat kering kan sampel dengan menggunkan oven selama 24 jam lalu ditimbang untuk mendapatkan berat kering[6].

b. Uji Sifat Mekanik Batuan

Langkah pertamama preparasi sampel yang tidak beraturan dengan ketentuan D (jarak antar konus) / W (lebar sisi bawah dan sisi atas sampel $)=$ 
1,0 - 1,4 cm, langkah kedua letakkan sampel diantara dua konus penekan alat point load indeks dan dongkrak hidrolik untuk nmemberikan tekanan pada contoh hingga sampai sampel pecah atau retak, catat nilai indeks strengh dari pengujian sampel tersebut[7].

\section{Teknis Analisis Data}

\section{Teknik Analisis Kualitas Massa Batuan}

Sistem klasifikasi massa batuan dengan RMR menggunakan enam parameter dasar untuk pengklasifikasian dan evaluasi hasil uji. Keenam parameter tersebut membantu perkiraan lebih lanjut hasil analisis stabilitas sampai permasalahan khusus geomekanika batuan. Keenam parameter yang digunakan untuk menentukan nilai RMR meliputi uji beban titik/point load test, rock quality designation (RQD), spasi diskontinuitas, keadaan diskontinuitas, keadaan air tanah dan orientasi diskontinuitas (Bieniawski, 1989) [8].

\section{Analisa parameter mekanik batuan}

Uji sifat mekanik diperlukan untuk mendapatkan nilai kuat tekan massa batuan yang nantinya diguanakan pada software RocLab untuk mendapatkan nilai kohesi dan sudut geser dalam.

\section{Teknik Analisa Potensi Longsor}

Untuk mengetahui jenis longsoran yang terdapat di daerah penelitian dilakukan menggunakan bantuan software dips. Data yang digunakan untuk analisa jenis longsor adalah data dip, dip direction, sudut geser dalam, dan lateral limit. Data tersebut dimasukkan ke software dips kemudian akan diketahui jenis longsoran yang terdapat di lereng tersebut.

4. Teknik Analisis Kestabilan Lereng Dilakukan Dengan Metode Hoek \& Bray Berdasarkan Jenis Potensi Longsor

Analisis kestabilan lereng dilakukan secara manual menggunakan metode analisis Hoek \& Bray berdasarkan jenis potensi longsor. Hoek \& Bray dengan metodenya yaitu General Limit Equilibrium (GLE) / kesetimbangan batas[9].
Analisis kestabilan lereng dilakukan menggunakan metode kesetimbangan batas (limit equilibirum) untuk tipe longsoran guling. Tahap pertama dalam analisis ini adalah dengan menghitung dimensi masingmasing blok. Berdasarkan geometri lereng. Berdasarkan geometri lereng diketahui bahwa lereng mempunyai $\mathrm{n}$ buah blok yang terbentuk teratur dengan lebar blok adalah $\Delta_{\mathrm{x}}$ dan tinggi setiap blok adalah $\mathrm{y}_{\mathrm{n}}$, sementara itu tinggi lereng disimpulkan dengan $\mathrm{H}$.

Untuk mengetahui banyaknya blok batuan yang terdapat pada lereng batuan dilakukan perhitungan sebagai berikut:

$\mathrm{n}=\frac{H}{\Delta x}\left[\operatorname{Cosec}\left(\Psi_{b}\right)\left(\frac{\cot \left(\Psi_{b}\right)-\cot \left(\Psi_{f}\right)}{\sin \left(\Psi_{b}-\psi_{f}\right)}\right) \sin \left(\psi_{s}\right)\right]$

Keterangan:

$\mathrm{n}$ = Banyak nya blok yang terbentuk pada lereng

$\mathrm{H}=$ Tinggi lereng $(\mathrm{m})$

$\Delta \mathrm{x}=$ Lebar blok $(\mathrm{m})$

$\psi_{\mathrm{f}}=$ Sudut kemiringan lereng $\left(^{\circ}\right)$

$\psi_{\mathrm{b}}=$ Kemiringan muka lereng $\left(^{\circ}\right)$

$\psi_{\mathrm{s}}=$ Kemiringan lereng di atas $\operatorname{crest}\left({ }^{\circ}\right)$

Untuk keperluan analisis, penomoran blok dimulai dari bawah (toe) ke atas dengan blok paling bawah diberi nomor 1 dan blok paling atas diberi nomor $n$. Konstanta $a_{1}, a_{2}$ dan $b$ dapat dihitung dengan persamaan berikut:

$$
\begin{aligned}
& \mathrm{a}_{1}=\Delta_{\mathrm{x}} \cdot \tan \left(\psi_{\mathrm{f}}-\psi_{\mathrm{p}}\right) \\
& \mathrm{a}_{2}=\Delta_{\mathrm{x}} \cdot \tan \left(\psi_{\mathrm{p}}-\psi_{\mathrm{s}}\right) \\
& \mathrm{b}=\Delta_{\mathrm{x}} \cdot \tan \left(\psi_{\mathrm{b}}-\psi_{\mathrm{p}}\right)
\end{aligned}
$$

Keterangan:

$\mathrm{a}_{1}=$ Perbedaan ketinggian di bagian atas blok yang berdekatan di bawah puncak lereng (m)

$\mathrm{a}_{2}=$ Perbedaan ketinggian di bagian atas blok yang berdekatan di atas puncak lereng $(\mathrm{m})$

$\mathrm{b}$ = Perbedaan ketinggian di dasar blok yang berdekatan $(\mathrm{m})$

$\psi_{\mathrm{p}}=$ Sudut kemiringan bidang $\left(^{\circ}\right)$ 
Selanjutnya berdasarkan Hoek \& Bray (2005) analisis longsoran toppling dilakukan dengan cara sebagai berikut:

a. Menghitung tinggi blok ke-n $\left(\mathrm{y}_{\mathrm{n}}\right)$ dihitung dengan persamaan berikut:

1. Untuk blok dari crest ke bawah $\mathrm{y}_{\mathrm{n}}=\mathrm{n}(\mathrm{a} 1-\mathrm{b})$

2. Untuk blok di atas crest

$\mathrm{y}_{\mathrm{n}}=\mathrm{y}_{\mathrm{n}-1}-\mathrm{a}_{2}-\mathrm{b}$

Keterangan:

$\mathrm{y}_{\mathrm{n}} \quad=$ Tinggi blok ke-n (m).

Model longsoran guling dapat dilihat pada gambar 2 dibawah ini.

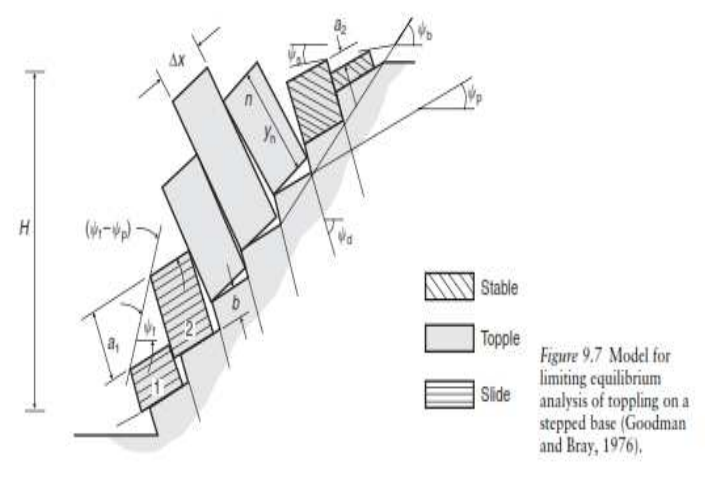

Gambar 2. Model Longsoran Guling Untuk Model Kesetimbangan Batas(Goodman And Bray, 1976).

Berdasarkan model pada Gambar 2, terdapat tiga grup blok yang mempunyai tingkat kemantapan yang berbeda yaitu:

1. Satu set blok yang stabil (di bagian atas) ketika sudut geser dalam material lebih besar dari dip bidang $\left(\phi_{\mathrm{p}}>\psi_{\mathrm{p}}\right)$

2. Satu set blok yang akan terguling (di bagian tengah)

3. Satu set di daerah toe, yang terdorong oleh blok toppling di atasnya. Blok ini mungkin stabil, terguling, atau tergelincir, tergantung dari kemiringan dan geometri blok. Kondisi kesetimbangan batas blok ke-n yang akan terguling dan yang akan tergelincir dapat dilihat pada gambar 3 dibawah ini.

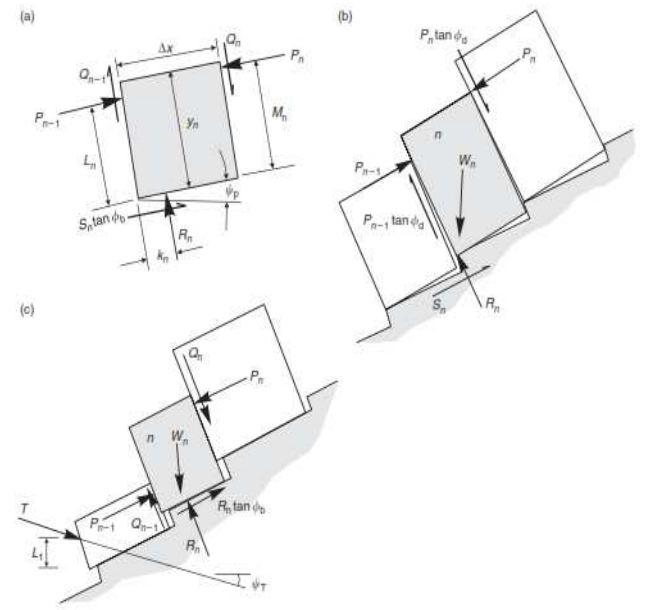

\section{Gambar 3. Kondisi Kesetimbangan Batas Blok ke-n yang Akan Terguling dan Tergelincir (Goodman dan Bray, 1976).}

Dari gambar tersebut terlihat bahwa gaya-gaya yang bekerja pada blok ke-n adalah Rn dan Sn, sedangkan gaya-gaya yang bekerja di interface (dengan blok terdekat) adalah Pn, dan Pn-1. Selanjutnya menghitung dimensi blok.

b. Menghitung dimensi blok Ln, Mn, Kn, dapat dihitung dengan persamaan berikut ini.

1. Untuk blok di bawah crest lereng

$$
\mathrm{M}_{\mathrm{n}}=\mathrm{Y}_{\mathrm{n}}
$$$$
\mathrm{L}_{\mathrm{n}}=\mathrm{Y}_{\mathrm{n}}-\mathrm{a}_{1}
$$

2. Untuk blok tepat di crest lereng

$$
\begin{aligned}
& \mathrm{M}_{\mathrm{n}}=\mathrm{Y}_{\mathrm{n}}-\mathrm{a}_{2} \\
& \mathrm{~L}_{\mathrm{n}}=\mathrm{Y}_{\mathrm{n}}-\mathrm{a}_{1}
\end{aligned}
$$

3. Untuk blok di atas crest lereng

$$
\begin{aligned}
& \mathrm{M}_{\mathrm{n}}=\mathrm{Y}_{\mathrm{n}}-\mathrm{a}_{1} \\
& \mathrm{~L}_{\mathrm{n}}=\mathrm{Y}_{\mathrm{n}}
\end{aligned}
$$

c. Menghitung nilai massa blok (Wn) dapat dilakukan dengan persamaan berikut ini.
1. $\mathrm{M}=\operatorname{vx} \rho$
2. $\mathrm{Wn}=\mathrm{m} \times \mathrm{g} \times \mathrm{a}$

d. Menentukan blok yang terguling dengan syarat $\mathrm{y}_{\mathrm{n} /} \Delta \mathrm{x}<\cot \left(\psi_{\mathrm{p}}\right)$,

e. Menghitung nilai $P_{n-1, t}$ dan $P_{n-1, s}$ 
$\mathrm{P}_{\mathrm{n} 1, \mathrm{t}} \frac{\left[\operatorname{Pn}(M n-\Delta x \cdot \operatorname{Tan} \phi)+\left(\frac{W n}{2}\right)\left(y n \cdot \sin \psi_{p}-\Delta x \cdot \cos \psi_{p}\right)\right]}{L n}$

Pn $=0$ ( untuk blok teratas dari set yang terguling)

$=\mathrm{P}_{\mathrm{n}-1}$ (untuk blok yang terguling dibawahnya).

$\mathrm{P}_{\mathrm{n}-1, \mathrm{~s}}=\operatorname{Pn} \frac{\left[\text { Wn }\left(\cdot \operatorname{Tan} \phi \cdot \cos \psi_{p}-\sin \psi_{p}\right)\right]}{1-\tan ^{2} \phi}$

Pn $\quad=$ Pn-1,t (untuk blok teratas dari set blok yang tergelincir)

$=$ Pn-1,s (untuk blok terguling dibawahnya, disini akan terlihat $\mathrm{Pn}, \mathrm{t}>\mathrm{Pn}, \mathrm{s})$.

f. Sementara untuk gaya-gaya $R_{n}, S_{n}$ dihitung dengan persamaan berikut ini:

g.

$$
\begin{aligned}
& \mathrm{Rn}=\mathrm{Wn} \cos \psi_{\mathrm{p}}+\left(\mathrm{P}_{\mathrm{n}}-\mathrm{P}_{\mathrm{n}-1}\right) \operatorname{ta} \phi \\
& \mathrm{Sn}=\mathrm{Wn} \sin \psi_{\mathrm{p}}+\left(\mathrm{P}_{\mathrm{n}}-\mathrm{P}_{\mathrm{n}-1}\right)
\end{aligned}
$$

h. Menentukan nilai FK dapat dilakukan dengan cara berikut ini.

$$
\mathrm{Sn} / \mathrm{Rn}
$$

\section{Analisis Perlakuan Agar Didapatkan} Kondisi Lereng Aman

Adapun maksud dari perkuatan lereng adalah Membantu massa batuan untuk menyangga dirinya sendiri. Jika pada lereng perlu ditambah perkuatan, maka selanjut nya yang perlu dilakukan adalah menentukan jenis perkuatan yang perlu ditetapkan untuk lereng tersebut.

\section{Analisis FK Menggunkan Software Slide V6.0}

Adapun prosedurnya adalah:

a. Buka Software slide V6.0.

b. Lakukan pengaturan project dengan cara klik analysis-project setting

c. Klik draw polyline-klik koordinat

d. Klik import koordinat penampang pada coordinate table-enter

Sehingga gambar penampang muncul pada lembar kerja.

\section{HASIL DAN PEMBAHASAN \\ Geometri Lereng}

Geometri lereng dapat dilihat pada Gambar 4,

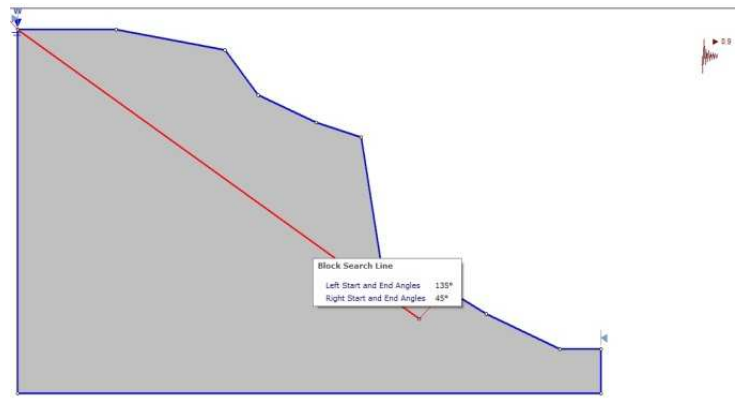

Gambar 4. Geometri lereng

\section{Uji Sifat Fisk Batuan}

Rangkuman hasil pengolahan dari uji sifat fisik

\begin{tabular}{|c|c|c|c|c|c|c|c|c|c|c|}
\hline mpel & $\begin{array}{l}\text { Bobot } \\
\text { isi asli } \\
(\mathrm{g} / \mathrm{cm} 3)\end{array}$ & $\begin{array}{c}\text { Bobot } \\
\text { isi } \\
\text { keing } \\
(\mathrm{g} / \mathrm{cm} 3)\end{array}$ & $\begin{array}{l}\text { Bobot } \\
\text { isi jemuh } \\
(\mathrm{g} / \mathrm{cm} 3)\end{array}$ & $\begin{array}{l}\text { Berat } \\
\text { Jenis } \\
\text { semu }\end{array}$ & $\begin{array}{l}\text { SG } \\
\text { asli }\end{array}$ & $\begin{array}{c}\text { Kadar } \\
\text { Air } \\
\text { Asli } \\
(\%)\end{array}$ & $\begin{array}{c}\text { Kadar } \\
\text { Air } \\
\text { Jenuh } \\
(\%)\end{array}$ & $\begin{array}{c}\text { Derajat } \\
\text { Kejenuhan } \\
(\%)\end{array}$ & tas & $\begin{array}{l}\text { Angka } \\
\text { pon }\end{array}$ \\
\hline 1 & 2664 & 2,657 & 2,671 & 2,657 & 2,695 & 0,267 & 0,538 & 49,6 & 1,430 & 0,01 \\
\hline 2 & 2,648 & 2,634 & 2,660 & 2,634 & 2,703 & 0,507 & 0,964 & 52,5 & 2,540 & 0,026 \\
\hline 3 & 2,661 & 2,646 & 2,668 & 2,646 & 2,706 & 0,570 & 0,846 & 67,36 & 2,239 & 0,02290 \\
\hline 4 & 2,683 & 2,676 & 2,689 & 2,676 & 2,712 & 0,252 & 0,505 & 50,00 & 1,351 & 0,01369 \\
\hline ta-rata & 2,664 & 2,653 & 2,672 & 2,653 & 2,704 & 0,399 & 0,713 & 54,89 & 1,890 & 0,01929 \\
\hline
\end{tabular}
dapat dilihat pada tabel 1 .

Tabel 1. Rangkuman hasil pengolahan dari uji sifat fisik 


\section{Uji Sifat Mekanik Batuan}

Hasil pengujian beban titik / PLI dapat dilihat pada tabel 2 di bawwah ini.

Tabel 2 hasil pengujian beban titik/PLI

\begin{tabular}{ccccc}
\hline Sample & $\begin{array}{c}\text { Panjang } \\
(\mathrm{cm})\end{array}$ & $\begin{array}{c}\text { Diameter } \\
(\mathrm{cm})\end{array}$ & $\begin{array}{c}\text { Indeks Streng } \\
(\mathrm{Mpa})\end{array}$ & $\begin{array}{c}\text { Kuat Tekan } \\
(\mathrm{Mpa})\end{array}$ \\
\hline $\mathbf{l}$ & 6,02 & 3,04 & 2,05 & 38,95 \\
2 & 6,03 & 3,06 & 2,16 & 41,04 \\
3 & 6,05 & 3,05 & 2,11 & 40,09 \\
4 & 6,03 & 3,08 & 32,24 & 42,56 \\
& Rata-Rata & & $\mathbf{2 , 1 4}$ & 40,86 \\
\hline
\end{tabular}

Untuk mendapatkan nilai kohesi dan sudut geser dalam di lakukan dengan bantuan software roclab, hasil dari software roclab dijelaskan pada tabel 3 berikut ini.

Tabel 3 Output data parameter rocklab

\begin{tabular}{lcc}
\hline No & Data masukan & Nilai \\
\hline $\mathbf{l}$ & Kuat tekan batuan & $40,86 \mathrm{Mpa}$ \\
$\mathbf{2}$ & GSI & 54 \\
$\mathbf{3}$ & Jenis batuan $(\mathrm{Mi})$ & 10 \\
$\mathbf{4}$ & Bobot isi jenuh $(\mathrm{MN} / \mathrm{m} 3)$ & 0,0267 \\
\hline
\end{tabular}

\section{Klasifikasi Massa Batuan (Sistem RMR)}

Hasil klasifikasi massa batuan di. idapatkan nilai RMR yaitu sebesar 59, sehingga dapat disimpulkan bahwa batuan termasuk dalam golongan III dengan kualitas massa batuan sedang. Hasil dari sistem rmr dijelaskan pada tabel 4 dibawah ini.

Tabel 4 Kelas massa batuan sistem RMR

\begin{tabular}{lcc}
\hline \multicolumn{1}{c}{ Parameter } & Nilai & Bobot \\
\hline RQD (\%) & $84,79 \%$ & 17 \\
Kuat Tekan(PLI) & $2,14 \mathrm{Mpa}$ & 7 \\
Spasi (mm) & $60-200 \mathrm{~mm}$ & 8 \\
Kondisi Discontinuitas & & \\
$\quad$ 1. Persistence (m) & $<1 \mathrm{~m}$ & 6 \\
2. Lebar Rongga (mm) & $0.1-5 \mathrm{~mm}$ & 1 \\
3. Kekasaran Kekar & Sedikit kasar & 3 \\
4. Material Pengisi & sand(Lunak <5mm) & 2 \\
5. Pelapukan & Sedikit lapuk & 5 \\
Kondisi Air & Lembab & 10 \\
Orientasi kekar & Menguntungkan (Dip rata-rata $>45$ yaitu & 0 \\
& $58)$ & $\mathbf{5 9}$ \\
\hline
\end{tabular}

\section{Analisis Tipe Longsoran} Analisis kinematik longsoran toppling

a. Flexural toppling

Pada hasil analisis didapatkan kemungkinan terjadinya flexural toppling sebesar $0,00 \%$. Hasil analisis dari software dips ini menunjukkan bahwa lereng pada lokasi penelitian tidak memiliki resiko terjadinya longsor tipe Flexural Toppling. Analisis kinematik dari longsoran flexural toppling dapat dilihat pada gambar 5 dibawah ini.
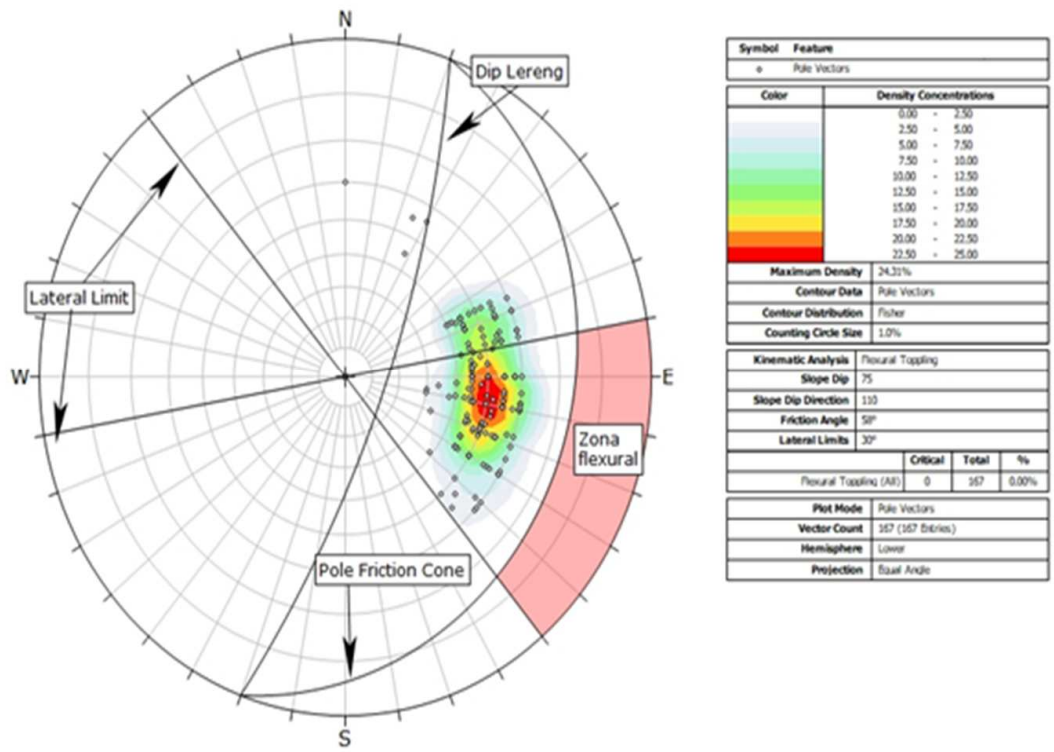

Gambar 5. Output analisis kinematik flexural toppling 
b. Direct toppling

Berdasarkan gambar tersebut diketahui bahwa terdapat titik - titik intersections yang berada pada zona longsor direct toppling dengan persentasi sebesar 38,66\%. Analisis kinematik dari longsoran direct toppling dapat dilihat pada gambar 6 di halaman berikut.
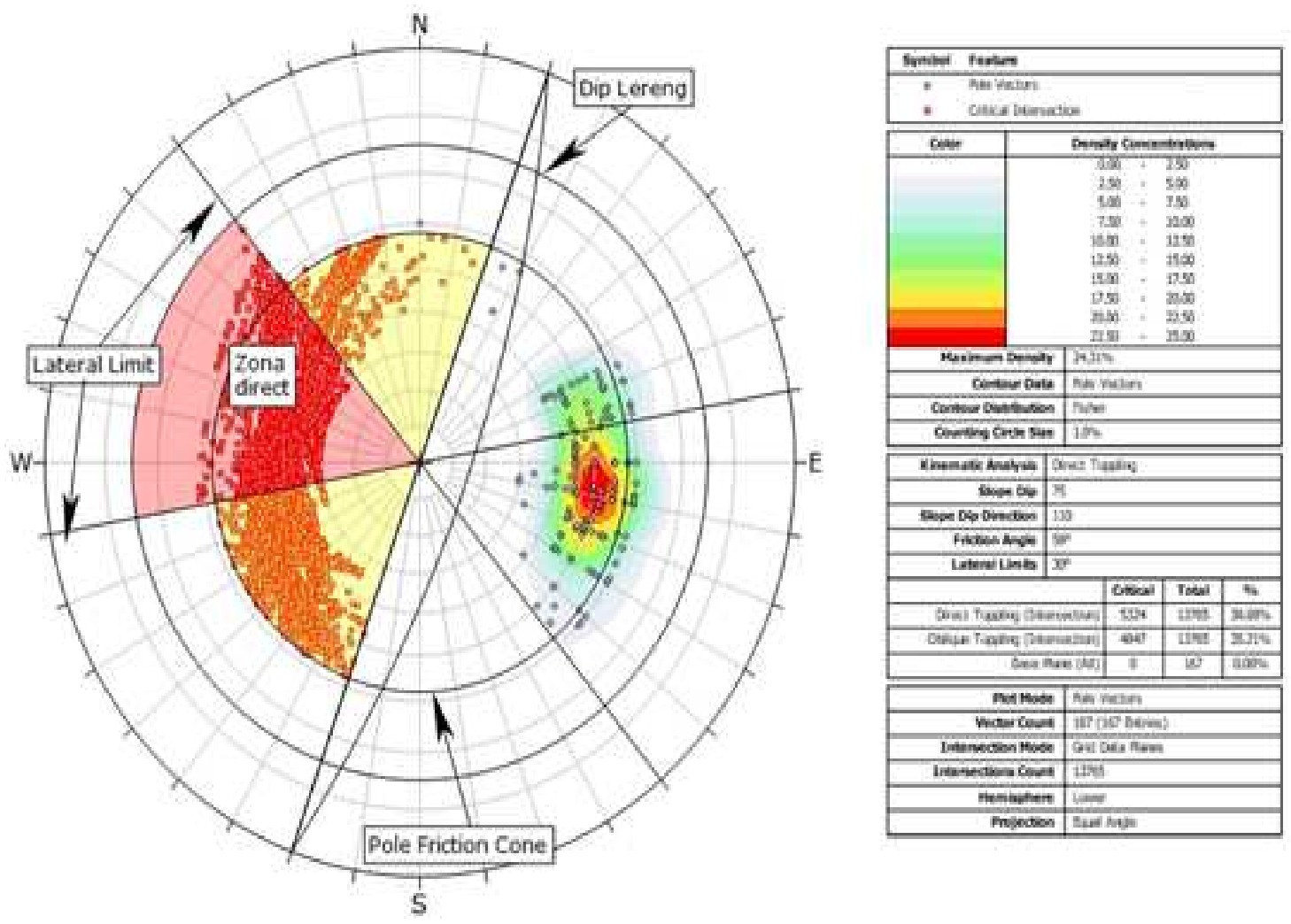

Gambar 6. Output Analisis Kinematik Direct Toppling

\section{Analisis kinematik longsoran baji}

Daerah yang menjadi zona terjadinya longsor baji berada diluar posisi lereng dan didalam kerucut geser (friction cone). Berdasarkan gambar tersebut diketahui bahwa terdapat titik - titik intersections yang berada pada zona longsor baji dengan persentasi sebesar $0,00 \%$. Analisis kinematik dari longsoran baji dapat dilihat pada gambar 7 berikut ini. 

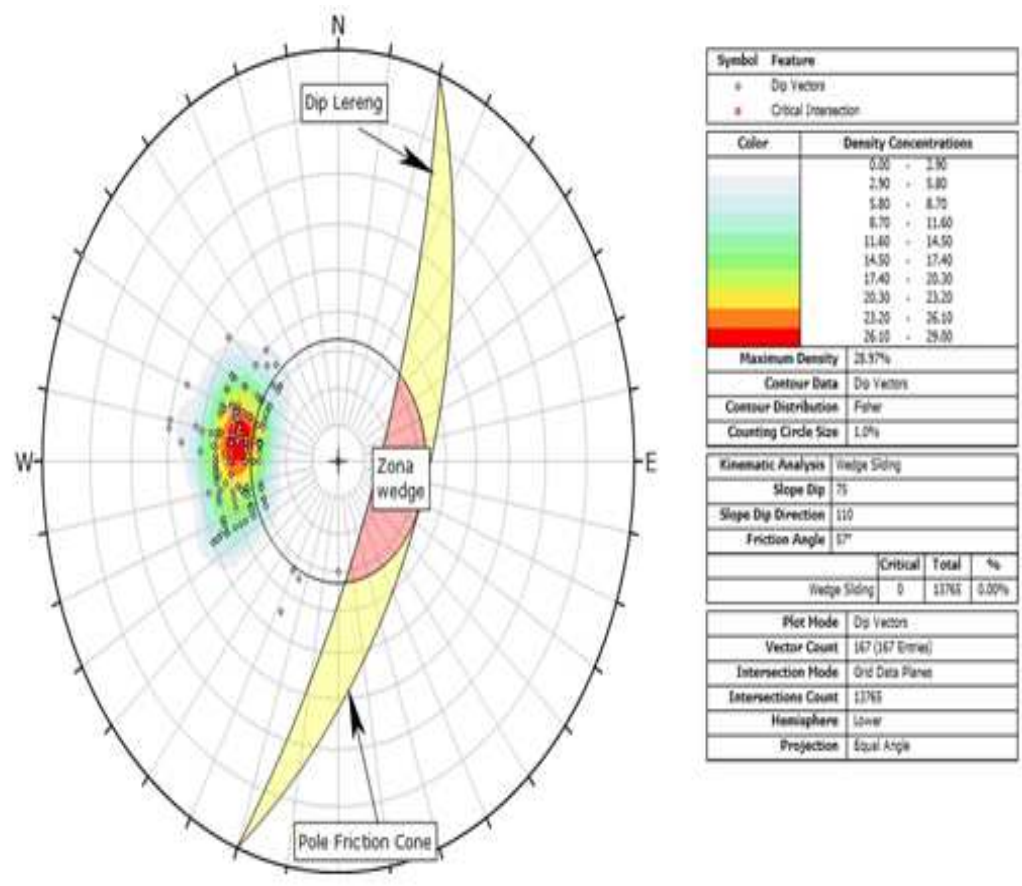

Gambar 7. Output analisis kinematik wedge failure

\section{Analisis kinematik longsoran bidang}

Plane failure akan terjadi apabila terdapat titik-titik pole di kawasan tersebut, sehingga disimpulksn lereng tidak terdapat potensi longsoran tersebut. Analisis kinematik dari longsoran baji dapat dilihat pada gambar 8 berikut ini.
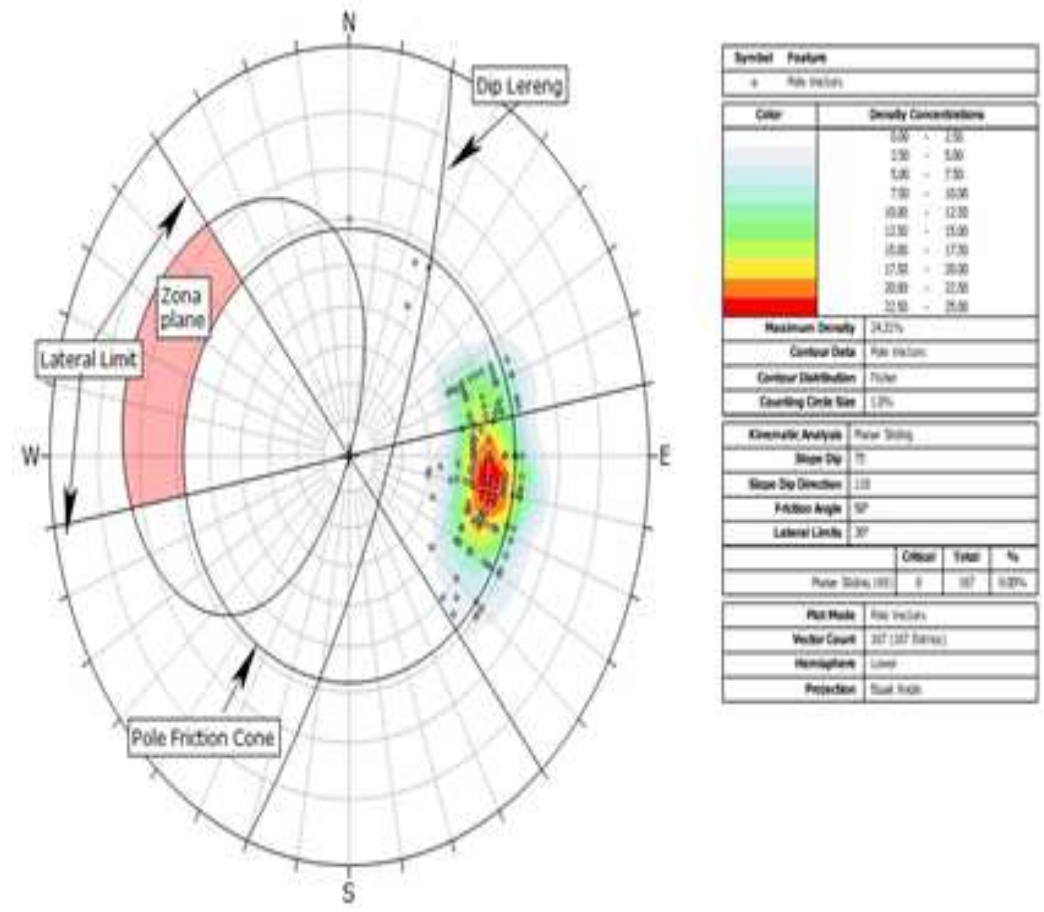

Gambar 8. Output analisis kinematik plane failure 
Analisis Kestabilan Lereng Menggunakan Metode Kesetimbangan Batas

Kondisi kestabilan lereng didapatkan dari nilai faktor keamanan hasil analisis manual kesetimbangan batasi dengan metode Hoek \& Bray. Analisis kestabilan ini mendapatkan nilai faktor keamanan lereng pada saat kondisi asli. Longsoran toppling terjadi pada lereng yang terjal dan batuan yang keras dengan struktur bidang lemahnya yang berbentuk kolom. Geometri balok batuan pada lokasi penelitian dapat dilihat pada gambar 9 dibawah ini. Berdasarkan penggambaran kondisi lereng di lapangan didapatkan beberapa parameter yang dibutuhkan untuk analisis longsoran toppling seperti yang terdapat pada Tabel 5

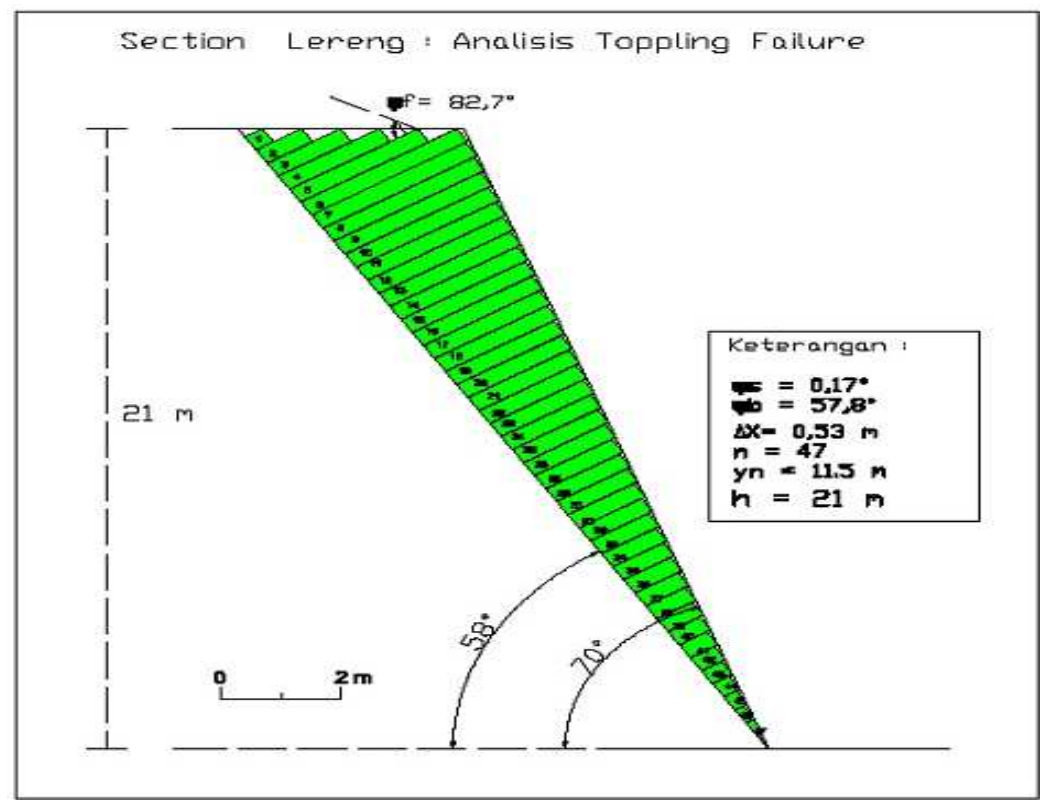

Gambar 9. Geometri Blok Batuan pada Lokasi Penelitian

Tabel 5. Nilai parameter analisis longsor toppling

\begin{tabular}{cc}
\hline Parameter & Nilai \\
\hline$\psi_{\mathrm{P}}$ & $57,62\left(^{\circ}\right)$ \\
$\psi_{\mathrm{S}}$ & $0,17\left(^{\circ}\right)$ \\
$\psi_{\mathrm{F}}$ & $82,7\left(^{\circ}\right)$ \\
$\psi_{\mathrm{b}}$ & $57,8\left(^{\circ}\right)$ \\
$\mathbf{\Phi}$ & $58,09\left(^{\circ}\right)$ \\
$\Delta \mathbf{x}$ & $0,53(\mathrm{~m})$ \\
\hline
\end{tabular}

Parameter yang ditampilkan pada Tabel 5 didapatkan sebagai berikut:

Sudut kemiringan dasar blok $\left(\psi_{\mathrm{p}}\right)$

Nilai parameter ini diambil dari nilai rata-rata dip hasil pengukuran. Nilai $\psi_{\mathrm{p}}$ sebesar $57,62^{\circ}$.

\section{Sudut kemiringan lereng di atas crest $\left(\psi_{s}\right)$}

$\psi_{\text {s }}$ merupakan sudut di atas crest lereng. Cara untuk mendapatkan nilai sudut $\psi_{\mathrm{s}}$ menggunakan rumus sebagai berikut:

$\psi_{\mathrm{s}}=\arctan \mathrm{a}$

dimana nilai a diperoleh menggunakan persamaan:

$$
\begin{aligned}
\mathrm{a} & =\frac{\text { lebar rongga }}{\text { persistance }} \\
& =0.0050 \mathrm{~m} \\
\psi_{\mathrm{s}} & =\arctan \mathrm{a} \\
& =\arctan (0,0050) \\
& =0,17^{\circ} .
\end{aligned}
$$


Sudut permukaan lereng $\left(\psi_{f}\right)$

Ilustrasi sudut $\psi_{\mathrm{f}}$ dapat dilihat pada Gambar 10, dan hasil perhitungan $\psi_{\mathrm{f}}$ dapat dilihat pada tabel 6 berikut ini.

Tabel 6. Hasil Perhitungan $\psi f$ Pada blok Toppling

\begin{tabular}{|c|c|c|c|c|c|c|}
\hline Keminingan & $\begin{array}{l}\text { Delta } \\
\mathrm{y} \text { auto } \\
\text { real } 1 \\
\mathrm{~m}\end{array}$ & $\begin{array}{l}\text { delta y } \\
\text { auto } \\
\text { blok px }\end{array}$ & $\begin{array}{c}\text { delta } x \\
\text { auto } \\
\text { real } 1 \\
\mathrm{~m}\end{array}$ & $\begin{array}{c}\text { delt } x \\
\text { auto } \\
\text { block px }\end{array}$ & Gradien & $\begin{array}{c}\text { sudut } \\
\text { kemiringan }\end{array}$ \\
\hline A. 75 & 3.0729 & 241.38 & 0.1110 & 8.72 & 27.6811 & 87.93 \\
\hline B. 75 & 4.2991 & 337.7 & 0.9548 & 75 & 4.5026 & 77.47 \\
\hline $\begin{array}{c}\text { Nilai faktor } \\
\text { cad vs act }\end{array}$ & & & & 78.55 & & \\
\hline rata - rata & 3.6860 & 289.54 & 0.5329 & 41.86 & 16.0919 & 82.7 \\
\hline
\end{tabular}

Sisi tegak $(\Delta y)=27,6811^{\circ}$

Sisi alas $(\Delta x)=4,5026^{\circ}$

Melalui perhitungan menggunakan Persamaan 38, maka nilai $\psi_{\mathrm{f}}$ adalah sebagai berikut:

$$
\begin{aligned}
\psi_{\mathrm{f}} \quad & =\tan ^{-1} \frac{\Delta y+\Delta x}{2} \\
& =\tan ^{-1} \frac{27,68+4,50}{2} \\
& =\tan -1 \frac{87,93^{\circ}+77.47^{\circ}}{2} \\
& =82,7^{\circ}
\end{aligned}
$$

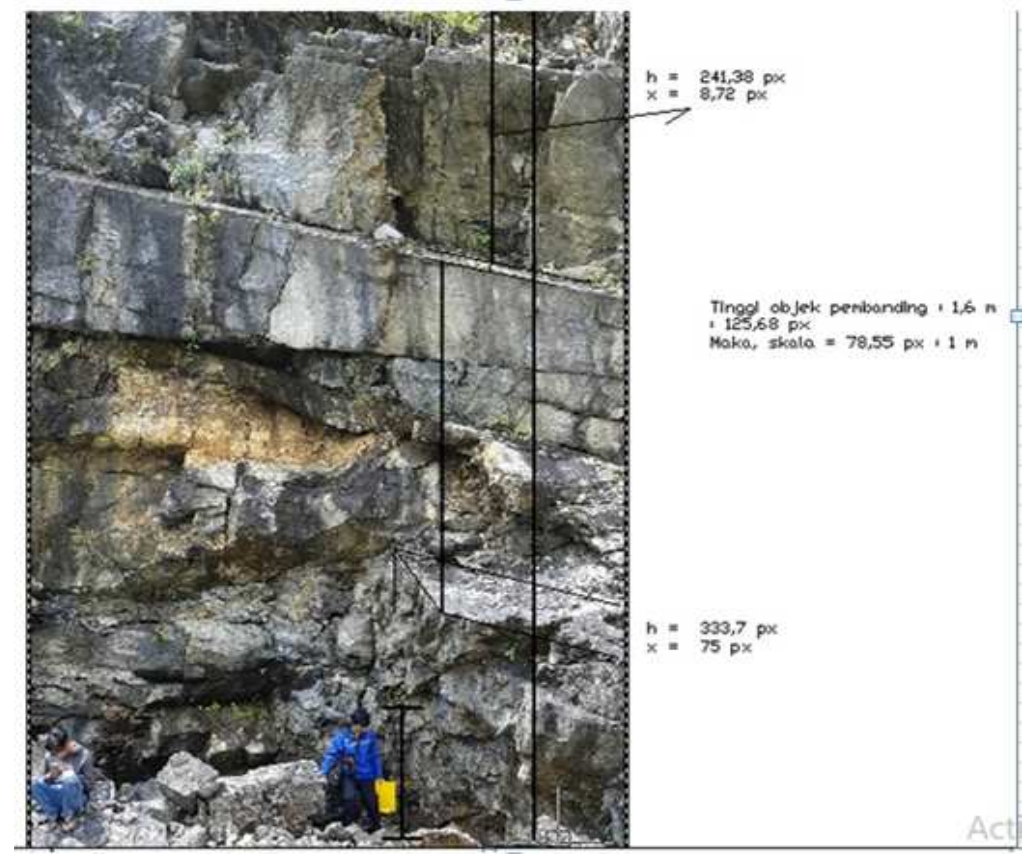

Gambar 10. Gambaran Ilustrasi Sudut $\psi f$

Keseluruhan kemiringan dasar blok toppling $\left(\psi_{b}\right)$

sehingga nilai $\psi_{\mathrm{b}}$ diperoleh dari perhitungan dibawah ini.

$$
\begin{aligned}
\psi_{\mathrm{b}} & =\psi_{\mathrm{p}}+\psi_{\mathrm{s}} \\
& =57,62^{\circ}+0,17^{\circ} \\
& =57,8^{\circ}
\end{aligned}
$$

Sudut geser dalam $(\varphi)$

Nilai sudut geser dalam telah didapatkan sebelumnya menggunakan bantuan software roclab sebesar $58,09^{\circ}$.

Lebar blok $(\Delta x)$

Nilai lebar blok didapatkan dari interpretasi foto lapangan yaitu $0,53 \mathrm{~m}$ 


\section{Banyak blok (n)}

Banyak nya blok yang terbentuk adalah 47 blok.

Selanjutnya dilakukan perhitungan untuk mendapatkan nilai konstanta $a_{1}, a_{2}$, dan $b$.

$$
\begin{aligned}
\mathrm{a}_{1} & =\Delta_{\mathrm{x}} \cdot \tan \left(\psi_{\mathrm{f}}-\psi_{\mathrm{p}}\right) \\
& =0,249 \mathrm{~m} \\
\mathrm{a}_{2} & =\Delta_{\mathrm{x}} \cdot \tan \left(\psi_{\mathrm{p}}-\psi_{\mathrm{s}}\right) \\
& =0,002 \mathrm{~m} \\
\mathrm{~b} & =\Delta_{\mathrm{x}} \cdot \tan \left(\psi_{\mathrm{b}}-\psi_{\mathrm{p}}\right) \\
& =0,002 \mathrm{~m}
\end{aligned}
$$

Selanjutnya berdasarkan Hoek and Bray (2005) analisis longsoran toppling dilakukan dengan cara:

\section{Menghitung tinggi blok $\left(\mathrm{y}_{\mathrm{n}}\right)$}

Untuk blok dari crest lereng ke bawah, karena blok ke-44 berada pada crest lereng dari 47 blok batuan.

$\mathrm{Yn}_{44}=10,87 \mathrm{~m}$

Untuk blok di atas crest yaitu blok ke-45, 46, 47.

$\mathrm{Y}_{45}=10,03 \mathrm{~m}$ (blok ke-45)

$\mathrm{Y}_{46}=9,19 \mathrm{~m}$ (blok ke- 46)

$\mathrm{Y}_{47}=8,36 \mathrm{~m}$ (blok ke-47)

Menghitung dimensi masing-masing blok (Ln, Mn, Kn)

Untuk blok di atas crest (blok ke- 45, 46, 47)

$$
\begin{aligned}
\mathrm{L}_{45} & =\mathrm{Y}_{45} \\
\mathrm{M}_{45} & =\mathrm{Y}_{45}-\mathrm{a}_{2} \\
& =10,03 \mathrm{~m}-0,835 \mathrm{~m} \\
& =9,20 \\
\mathrm{Kn} & =0
\end{aligned}
$$

Untuk blok tepat di crest (blok ke -44)

$$
\begin{array}{ll}
\mathrm{L}_{44} & =10,62 \mathrm{~m} \\
\mathrm{M}_{44} & =10,03 \mathrm{~m} \\
\mathrm{Kn} & =0
\end{array}
$$

Untuk perhitungan nilai $\mathrm{Wn}_{47}$ Tinggi blok (yn) $=8,36 \mathrm{~m}$

$$
\begin{aligned}
& \text { Lebar blok }(\Delta \mathrm{x}) \quad=0,533 \mathrm{~m} \\
& \text { Panjang blok }=24 \mathrm{~m} \\
& \text { Densitas batuan }(\rho)=2500 \mathrm{Kg} / \mathrm{m}^{3} \\
& \text { Faktor gempa (a) } \quad=0,9 \mathrm{~g} \\
& \mathrm{~m} \quad=\mathrm{vx} \rho \\
& =(8,36 \times 0,533 \times 24) \mathrm{m} \times 2500 \mathrm{Kg} / \mathrm{m}^{3} \\
& =267256,86 \mathrm{Kg} \\
& \mathrm{Wn}_{47}=\mathrm{mxg \times a} \\
& =235888,22 \mathrm{~N}
\end{aligned}
$$

Menentukan blok yang terguling dan tergelincir

Menentukan blok yang terguling $\Delta \mathrm{x} / \mathrm{y}_{\mathrm{n}}<\tan \psi_{\mathrm{p}}$ nilai dari $\tan \psi_{\mathrm{p}}=1,577^{\circ}$.

Untuk blok ke- 47 nilai $\Delta \mathrm{x} / \mathrm{y}_{\mathrm{n}}=0,06$

Untuk blok ke- 46 nilai $\Delta \mathrm{x} / \mathrm{y}_{\mathrm{n}}=0,058$

Untuk blok ke- 45 nilai $\Delta \mathrm{x} / \mathrm{y}_{\mathrm{n}}=0,053$

Menghitung nilai Pn,s dan Pn,t dimulai dari blok teratas hingga blok paling bawah

Untuk blok ke-47 dikarenakan blok berada dalam kondisi stabil maka nilai $\mathrm{Pn}, \mathrm{s}$ dan $\mathrm{Pn}, \mathrm{t}=0$, maka nilai $\mathrm{Pn}=0$.

Pada blok ke-46 merupakan blok teratas dari set yang terguling maka nilai $\mathrm{Pn}, \mathrm{t}$ dan $\mathrm{Pn}, \mathrm{s}=0$ dan nilai $\mathrm{Pn}=0$.

$$
\begin{aligned}
\mathrm{P}_{\mathrm{n}-1, \mathrm{t}} & =\frac{\left[\operatorname{Pn}(M n-\Delta x \cdot \operatorname{Tan} \phi)+\left(\begin{array}{c}
W n \\
2
\end{array}\right)\left(y n \cdot \sin \psi_{p}-\Delta x \cdot \cos \psi_{p}\right)\right]}{L n} \\
& =\frac{\left[0(8,36-0,533 \times 1,606)+\left(\frac{2595145,09}{2}\right)(9,19 \times 0,845-0,533 \times 0,536)\right]}{9,19} \\
& =1055534,69 \mathrm{~N} \\
\mathrm{P}_{\mathrm{n}-1, \mathrm{~s}} & =\operatorname{Pn}-\frac{\left[W n\left(\operatorname{Tan} \phi \cdot \cos \psi_{p}-\sin \psi_{p}\right)\right]}{1-\tan ^{2} \phi} \\
& =0-\frac{[2595145,09(1,606 \times 0,536-0,845)]}{1-2,579} \\
& =25504,68 \mathrm{~N}
\end{aligned}
$$




\section{Menentukan model longsoran yang terjadi pada blok}

Hasil dari perhitungan nilai $\mathrm{Pn}, \mathrm{t}$ dan $\mathrm{Pn}, \mathrm{s}$ digunakan untuk menentukan apakah blok yang dihitung akan terguling (toppling) atau tergelincir (sliding) dengan ketentuan berikut ini:

Blok akan terguling apabila Pn-1,t $>$ Pn-1,s dan nilai $\mathrm{Pn}-1=\mathrm{Pn}-1$,t.

Blok akan tergelincir apabila Pn-1,s $>$ Pn-1,t dan nilai Pn-1 $=$ Pn-1,s.

Jika Pn-1,t > Pn-1,s terjadi pada semua blok, maka blok akan terguling seluruhnya dan tidak ada blok yang tergelincir.

Menentukan nilai Rn dan Sn pada setiap blok $\mathrm{Rn}=\mathrm{Wn} \cos \psi_{\mathrm{p}}+\left(\mathrm{P}_{\mathrm{n}}-\mathrm{P}_{\mathrm{n}-1}\right) \tan \phi_{\mathrm{d}}$

$=180811 \times \cos 59,72+(0-0) \times \tan 64,71$

$=91076,55 \mathrm{~N}$

$\mathrm{Sn}=\mathrm{Wnsin} \psi_{\mathrm{p}}+\left(\mathrm{P}_{\mathrm{n}}-\mathrm{P}_{\mathrm{n}-1}\right)$

$=180811 \times \sin 59,72+(0-0)$

$=155983,81 \mathrm{~N}$

\section{Menentukan nilai FK}

Untuk blok ke-47

$$
\begin{aligned}
\mathrm{FK} & =\frac{S n}{R n} \\
& =\frac{936582,43 \mathrm{~N}}{1093747,963 \mathrm{~N}} \\
& =0,854
\end{aligned}
$$

Sehingga didasarkan dari perhitungan analisis menurut Hoek \& Bray didapatkan nilai FK keseluruhan dari perhitungan adalah1,539.

\section{Analisis Kestabilan Lereng Menggunakan Software Slide V6.0}

Parameter sifat fisik, mekanik, dan faktor yang menjadi data input pada analisis fakor keamanan (FK) lereng dapat dilihat pada tabel 7

\begin{tabular}{|c|c|c|c|c|c|c|}
\hline \multirow[t]{2}{*}{ Koordinat } & \multicolumn{5}{|c|}{$\begin{array}{c}\text { Sifat Fisik dan Mekanik Material Penyusun } \\
\text { Lereng }\end{array}$} & \multirow[t]{2}{*}{ Penganuh Faktor Gempa } \\
\hline & & Sifat fisi & & Sifat & ekanik & \\
\hline \multirow{3}{*}{$\begin{array}{c}S 0^{\circ} 28^{\prime} 21,3 \\
" \\
\mathrm{E} 100^{\circ} 24^{\prime} 00 \\
, 4^{\prime \prime}\end{array}$} & $\begin{array}{c}\text { Bobot } \\
\text { Isi }\end{array}$ & $\begin{array}{c}\text { Bobot } \\
\text { Isi }\end{array}$ & $\begin{array}{c}\text { Bobot } \\
\text { Isi }\end{array}$ & $\begin{array}{c}\text { Kohes } \\
\mathrm{i}\end{array}$ & $\begin{array}{l}\text { Sudut } \\
\text { Geser }\end{array}$ & \multirow[t]{2}{*}{$\begin{array}{l}\text { Nilai Faktor Gempa } \\
\text { (g) }\end{array}$} \\
\hline & $\begin{array}{l}\text { Asli } \\
\text { (gam } \\
/ \mathrm{cm} 3)\end{array}$ & $\begin{array}{l}\text { Kening } \\
\text { (gam/ } \\
\mathrm{cm} 3 \text { ) }\end{array}$ & $\begin{array}{l}\text { Asli } \\
\text { (gam } \\
/ \mathrm{cm} 3 \text { ) }\end{array}$ & (Mpa) & $\begin{array}{c}\text { Dalam } \\
\text { (degree } \\
\text { ) }\end{array}$ & \\
\hline & 26,12 & 26,01 & 26,20 & 0,406 & $58,09^{\circ}$ & $\begin{array}{lllll}0, & 0, & 0, & 0,8 & 0,9 \\
5 & 6 & 7 & & \end{array}$ \\
\hline
\end{tabular}
berikut ini.
Tabel 7. Analisis parameter software slide

\section{Faktor Keamanan Lereng (FK) dengan}

\section{Pengaruh Faktor Gempa}

Analisa lereng untuk mendapatkan berapa nilai faktor keamanan optimal dengan parameter kohesi, sudut geser dalam, dan bobot isi material serta kondisi air tanah yang nantinya akan dapat dipertimbangkan untuk evaluasi kemantapan lereng pada lokasi penelitian.

\section{a. Faktor keamanan Lereng Kondisi Kering dengan Pengaruh Faktor Gempa}

Kondisi lereng dalam keadaan kering adalah ketika tidak terdapat muka air tanah. Kemudian, input bobot isi yang digunakan adalah bobot isi kering, dan pengaruh faktor gempa $0.5-0,9$ g. gambar FK penampang lereng dalam kondisi kering dengan faktor gmpa dapat dilihat pada gambar 11 sampai 15 dengan faktor gempa $0,5 \mathrm{~g}$ sampai $0,9 \mathrm{~g}$ di bawah ini.

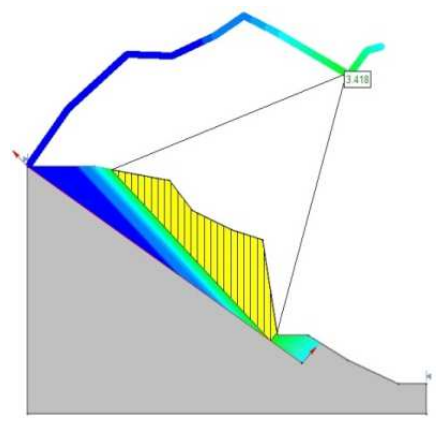

Gambar 11. FK Penampang dengan Getaran Gempa 0,5g 


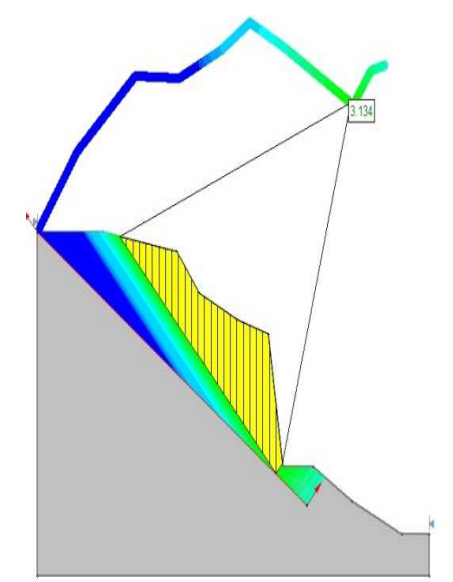

Gambar 12. FK Penampang dengan Getaran Gempa 0,6g

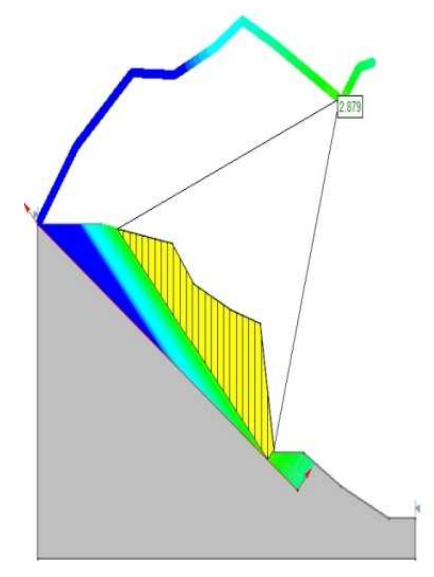

Gambar 13. FK Penampang dengan Getaran Gempa 0,7g
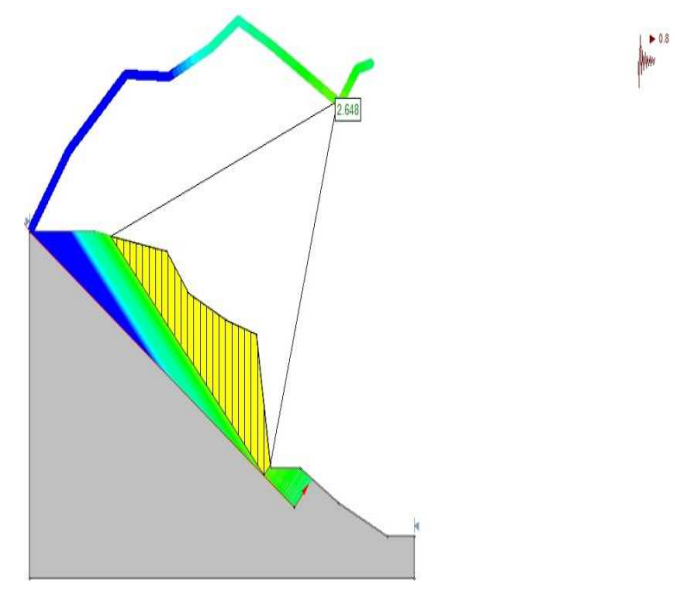

Gambar 14. FK Penampang dengan Pengaruh Gempa 0,8g

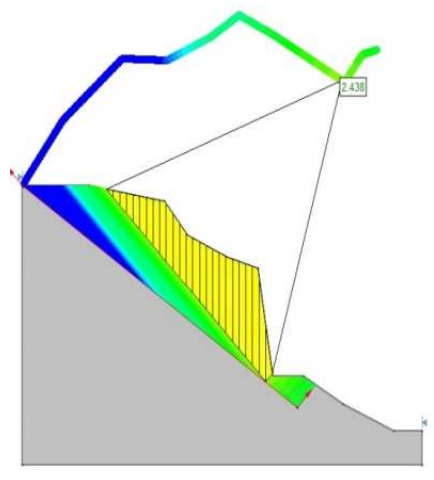

Gambar 15. FK Penampang dengan Pengaruh Gempa 0,9g

b. Faktor Keamanan Lereng Kondisi Asli dengan Pengaruh Faktor Gempa

Kondisi lereng dalam keadaan asli adalah ketika tidak terdapat muka air tanah. Kemudian, input bobot isi yang digunakan adalah bobot isi kering, dan bobot isi asli, dan pengaruh faktor gempa $0.5-0,9 \mathrm{~g}$. gambar FK penampang lereng dalam kondisi kering dengan faktor gempa dapat dilihat pada gambar 16 sampai 20 dengan faktor gempa $0,5 \mathrm{~g}$ sampai $0,9 \mathrm{~g}$ di bawah ini.

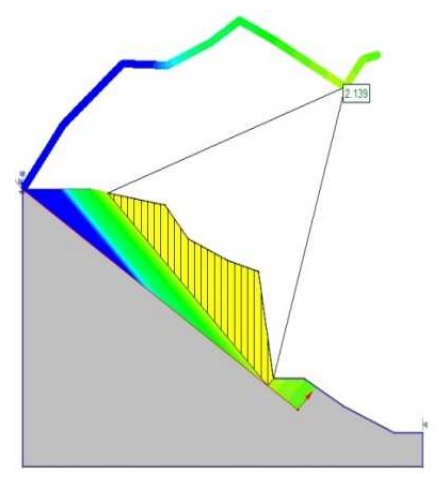

Gambar 16. FK Penampang dengan Pengaruh Gempa 0,5g 


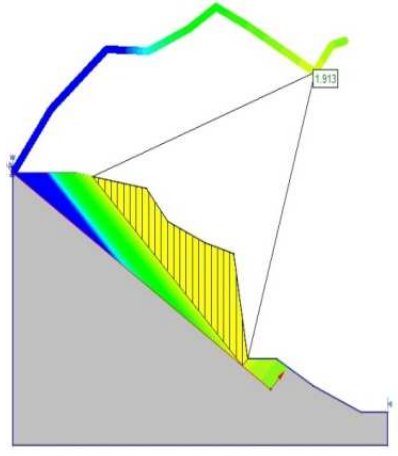

Gambar 17. FK Penampang dengan Pengaruh Gempa 0,6g

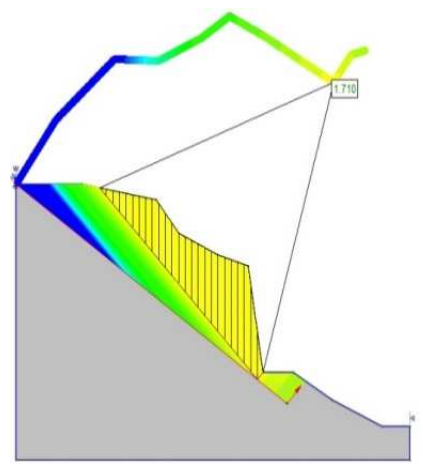

Gambar 18. FK Penampang dengan Pengaruh Gempa 0,7g

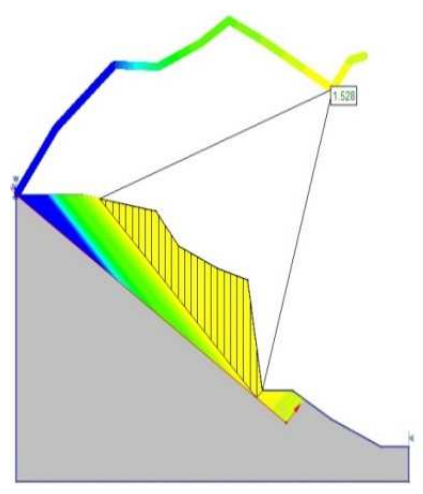

Gambar 19. FK Penampang dengan Pengaruh Gempa 0,8g

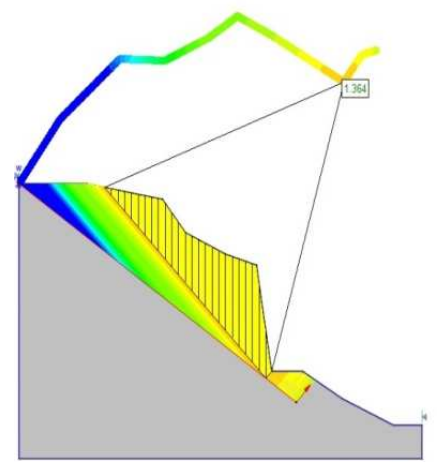

Gambar 20. FK Penampang dengan Pengaruh Gempa 0,9g

c. Faktor keamanan (FK) lereng Kondisi Jenuh dengan Pengaruh Faktor Gempa

Kondisi lereng dalam keadaan jenuh adalah ketika full terdapat muka air tanah. Kemudian, input bobot isi yang digunakan adalah bobot isi kering, dan bobot isi jenuh, dan pengaruh faktor gempa $0.5-0,9 \mathrm{~g}$. gambar FK penampang lereng dalam kondisi kering dengan faktor gempa dapat dilihat pada gambar 21 sampai 25 dengan faktor gempa $0,5 \mathrm{~g}$ sampai $0,9 \mathrm{~g}$ di halaman berikut.

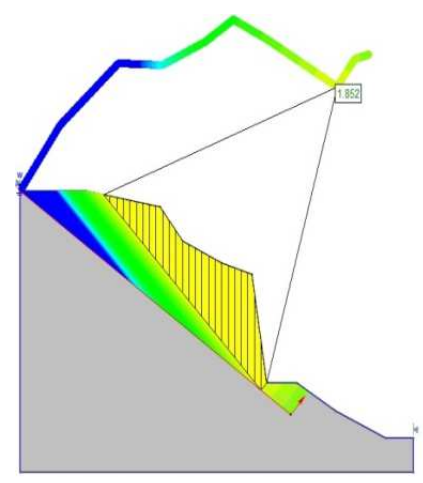

Gambar 21. FK Penampang dengan Pengaruh Gempa 0,5g 


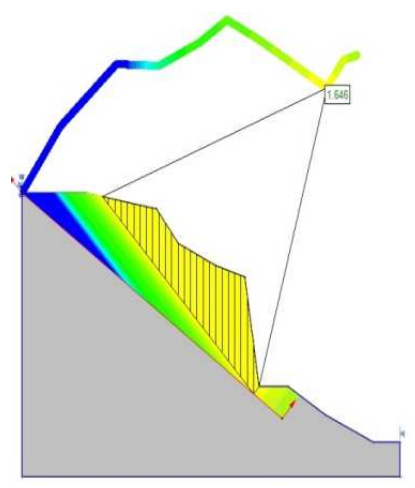

Gambar 22. FK Penampang dengan Pengaruh Gempa 0,6g

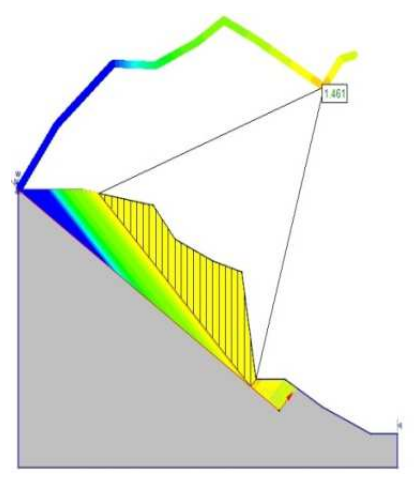

Gambar 23. FK Penampang dengan Pengaruh Gempa $0,7 \mathrm{~g}$

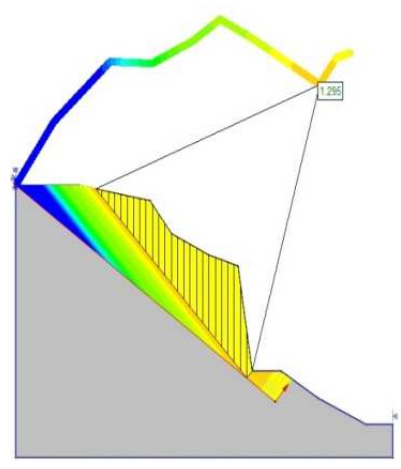

Gambar 24. FK Penampang dengan Pengaruh Gempa 0,8g

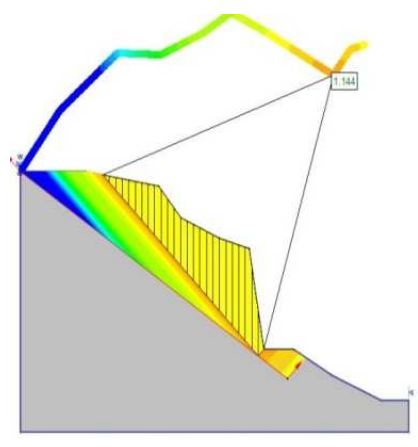

Gambar 25. FK Penampang dengan Pengaruh Gempa 0,9g

\section{Faktor Keamanan Lereng (FK) tampa Faktor Gempa}

Analisa lereng untuk mendapatkan berapa nilai faktor keamanan optimal dengan parameter kohesi, sudut geser dalam, dan bobot isi material serta kondisi air tanah yang nantinya akan dapat dipertimbangkan untuk evaluasi kemantapan lereng pada lokasi penelitian.

\section{a. Faktor keamanan Lereng Kondisi Kering}

Kondisi lereng dalam keadaan kering adalah ketika tidak terdapat muka air tanah. Kemudian, input bobot isi yang digunakan adalah bobot isi kering, gambar FK penampang lereng dalam kondisi kering dapat dilihat pada gambar 26 dibawah ni. Hasil analisis nilai faktor keamanan (FK) lereng dari kondisi kering adalah 4,385.

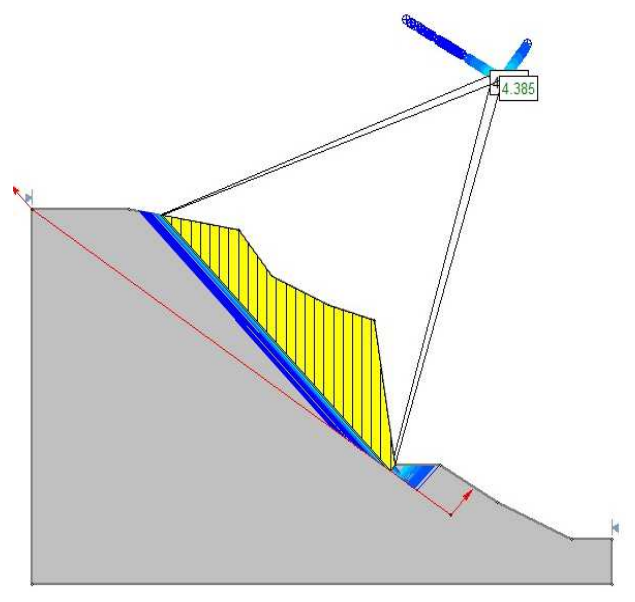

Gambar 26. FK Lereng Kondisi Kering 


\section{b. Faktor keamanan (FK) lereng Kondisi Asli}

Kondisi lereng dalam keadaan asli pada penelitian ini adalah ketika muka air tanah full saturated. Kemudian, input bobot isi yang digunakan adalah bobot isi kering dan bobot isi asli. Hasil analisis nilai faktor keamanan (FK) lereng penelitian pada kondisi asli adalah 3,869. Gambar fk dalam kondisi asli dapat diliahat pada gambar 27 dibawah ini.

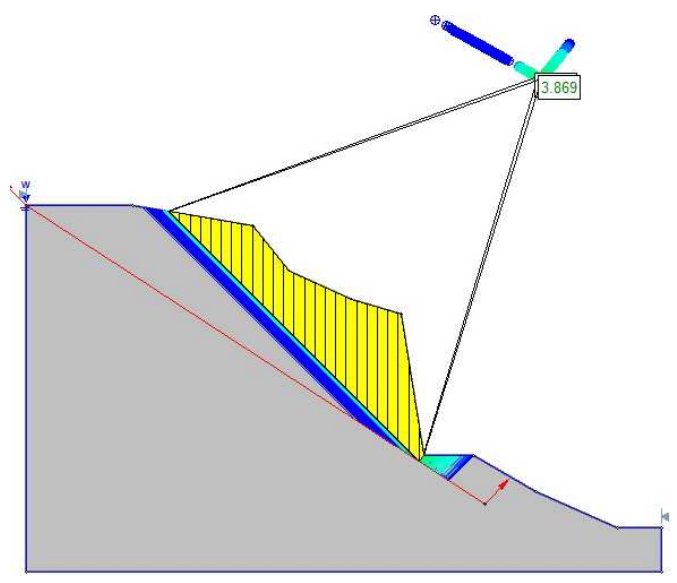

Gambar 27. FK Lereng Kondisi Asli

\section{c. Faktor keamanan (FK) lereng Kondisi Jenuh}

Kondisi lereng dalam keadaan asli pada penelitian ini adalah ketika muka air tanah full saturated. Kemudian, input bobot isi yang digunakan adalah bobot isi kering dan bobot isi jenuh dan ro air 1. Hasil analisis nilai faktor keamanan (FK) lereng penelitian pada kondisi jenuh adalah 1,144. Gambar FK penampang lereng dalam kondisi jenuh dapat dilihat pada gambar 28 berikut ini.

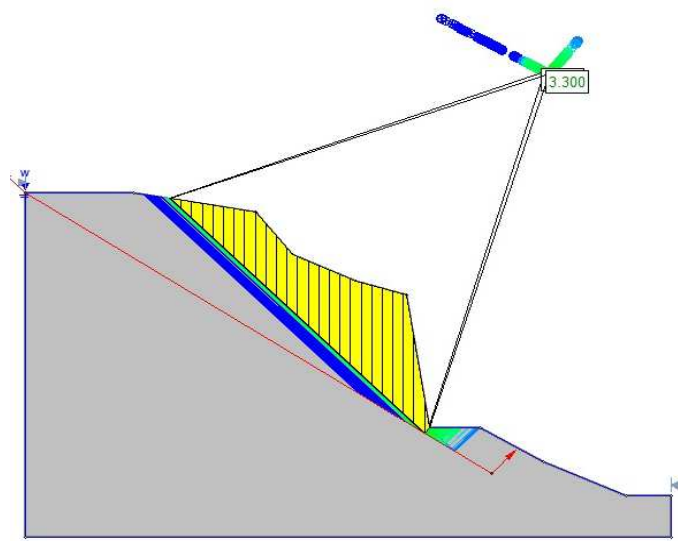

Gambar 28. FK Lereng Kondisi Jenuh

Rekapitulasi FK lereng keseluruhan dengan menggunakan software slide v6.0 dapat dilihat pada tabel 8 berikut ini.

Tabel 8. Rekapitulasi FK lereng penelitian

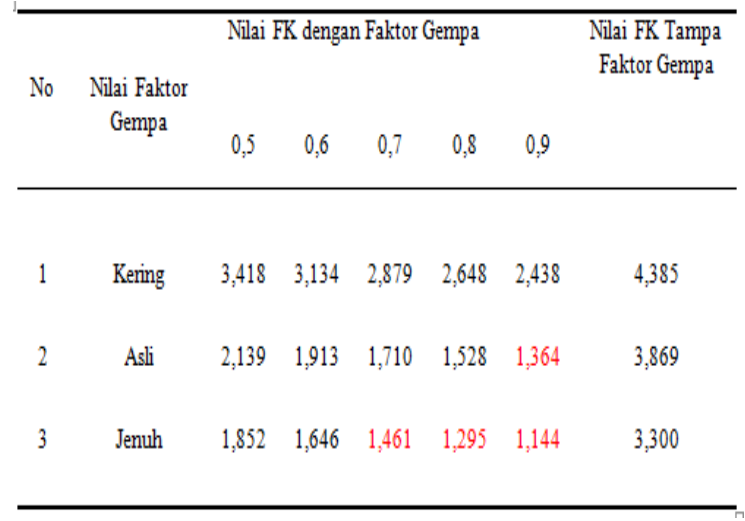

\section{Rekomendasi Perkuatan Lereng}

Dari hasil analisis lereng dalam kondisi tersebut, maka lereng dianggap perlu dilakukan perkuatan untuk menghindari bencana yang mungkin akan terjadi. Irwandy (2016) menyebutkan untuk mengatasi jatuhan batuan dapat dilakukan dengan cara pemasangan jaring kawat (wiremesh). Jaring kawat juga bisa digunakan untuk melokalisasi jatuhan batu. Bongkah-bongkah batu yang berpotensi runtuh akan ditahan oleh jala kawat yang terpasang pada lereng dan mencegah batu tersebut terpental ke jalan. Contoh pemasangan perkuatan lereng batan dapat dilihat pada gambar 29 berikut ini. 


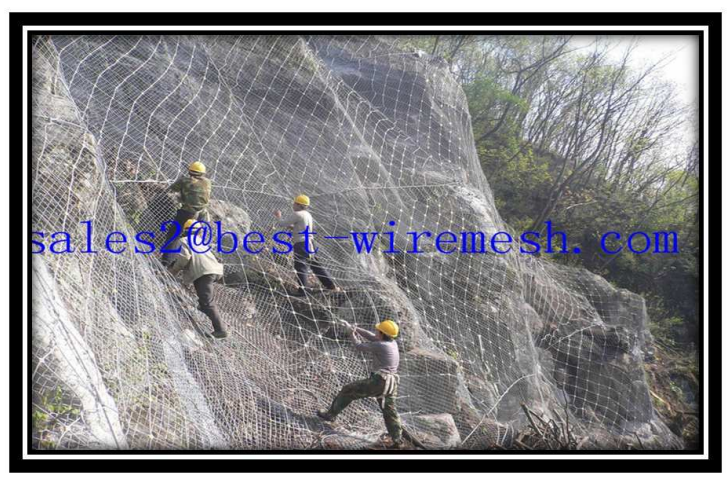

Gambar 29. Contoh Pemasangan Wiremesh pada Lereng Batuan

\section{KESIMPULAN}

1. Berdasarkan pengamatan di lapangan didapatkan geometri lereng dengan tinggi 21 $\mathrm{m}$, panjang $24 \mathrm{~m}$ dan sudut lereng $75^{\circ}$. Hasil dari pengujian sifat fisik dan sifat mekanik di laboratorium didapatkan sebagai berikut:

a. Hasil uji sifat fisik di laboratorium didapatkan nilai rata -rata seperti berikut: bobot isi Asli $=2,664 \mathrm{gr} / \mathrm{cm}^{3}$; bobot isi kering $=2,653 \mathrm{gr} / \mathrm{cm}^{3}$; bobot isi jenuh $=$ $2,672 \mathrm{gr} / \mathrm{cm}^{3}$; berat jenis semu $=2,653$; berat jenis asli $=2,704$; kadar air asli $=$ $0,399 \%$; kadar air jenuh $=0,713 \%$; derajat kejenuhan $=54,89 \%$; porositas $=$ $1,890 \%$; angka pori $=0,019$.

b. Berdasarkan hasil pengujian point load indeks pada sampel batuan didapatkan nilai Is $=2,14$ dan kuat tekan batuan $=$ 40,86 Mpa.

2. Berdasarkan perhitungan klasifikasi massa batuan menggunakan Rock Mass Rating System (RMR-System) didapatkan bahwa batuan termasuk dalam golongan III yang berarti batuan termasuk dalam golongan sedang.

3. Hasil analisis menggunakan software dips didapatkan bahwa kemungkinan jenis longsor yang terdapat di daerah penelitian adalah longsor tipe toppling failure.

4. Hasil analisis menggunakan metode kesetimbangan batas didapatkan nilai FK sebesar 1,539 hasil dari perhitungan tersebut, menunjukan lereng dalam keadaan stabil, dan analisis menggunakan software slide V6.0 menunjukan bahwa penampang lereng berada dalam keadaan tidak stabil pada saat muka air tanah full saturated, lereng dalam keadaan jenuh, dan pengaruh faktor gempa
0,7 -0,9g, dengan nilai FK 1,$461 ; 1,295$; 1,144. Kemudian nilai FK lereng juga berada dalam keadaan tidak stabil pada saat muka air tanah full saturated, lereng dalam kondisi asli, dan pengaruh faktor gempa $0,9 \mathrm{~g}$, dengan nilai FK 1,364.

5. Untuk mengantisipasi menurunnya nilai faktor keamanan pada lereng yang disebabkan oleh faktor alam dan manusia, maka rekomendasi yang pas untuk lereng yaitu dengan pemasangan beton tembak (shotcrete) dan pemasangan jaring kawat (wiremesh).

\section{DAFTAR PUSTAKA}

[1] I. Rusydy dkk. "Analisis Kestabilan Lereng Batu di Jalan Raya Lhoknga Km 17,8 Kabupaten Aceh Besar". Jurnal Riset Geologi dan Pertambangan, Vol. 27, No. 2 2017.

[2] Sandra, H., \& Anaperta, Y. M. "Analisis Kesetabilan Lereng Studi Kasus Area Tambang Rakyat di Bukit Tui S0 ${ }^{\circ} 8^{\prime} 43.15^{\prime \prime}$ E100 24'16.24"-S0 28'43.15"

E100²4'15.28" Kecamatan Padang Panjang Barat Kabupaten Padang Panjang" Bina Tambang, 3(4), 1657-1670. 2018.

[3] R.B. Pratamadkk. "Analisis Stabilitas Lereng Dan Alternatif Penanganannya (Studi Kasus Longsoran Jalan Alternatif Tawangmangu Sta 3+150 - Sta 3+200, Karanganyar)". Jurnal Karya Teknik Sipil, Vol. 3, No. 3. 2014.

[4] D.C. Wyllie, C.W. Mah. Rock Slope Engineering: Civil and Mining. 4rd. (ed). New York: Spoon PressLondon. 2004.

[5] N. Martono. Metode Penelitian Kuantitatif. Jakarta : Rajawali Pers. 2016.

[6] M.D. Braja. Mekanika Tanah PrinsipPrinsip Rekayasa Geoteknis. Jilid 1,2. Erlangga: Jakarta. 1995.

[8] Suedi, E., Kopa, R., \& Rusli, H. A. R. "Analisis Stabilitas Lereng Ruas Jalan Sicincin-Malalak Km 31 Kecamatan Malalak, Kabupaten Agam, Provinsi Sumatera Barat. Bina Tambang, 3(3), 12851299. 2018. 
[8] Bieniawski, Z.T. :Engineering Rock Mass Clasification. Canada: John Wiley \& Sons Inc. 1989.

[9] Hoek, E and Bray. J.W. Rock Slope Engineering. 4rd. ed. New York: Taylor \& Francis e-Library. 2005. 